Portland State University

PDXScholar

Environmental Science and Management

Faculty Publications and Presentations

$10-22-2015$

\title{
Convergence of Microclimate in Residential Landscapes Across Diverse Cities in the United States
}

Sharon J. Hall

Arizona State University

J Learned

Arizona State University

Benjamin Ruddell

Arizona State University

Kelli L. Larson

Arizona State University

Jeannine Cavender-Bares

University of Minnesota - St. Paul

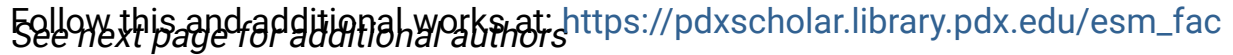

Part of the Environmental Sciences Commons

Let us know how access to this document benefits you.

\section{Citation Details}

Hall, S. J., Learned, J., Ruddell, B., Larson, K. L., Cavender-Bares, J., Morse, J. L., ... Trammell, T. L. E. (2015). Convergence of microclimate in residential landscapes across diverse cities in the United States. Landscape Ecology

This Article is brought to you for free and open access. It has been accepted for inclusion in Environmental Science and Management Faculty Publications and Presentations by an authorized administrator of PDXScholar. Please contact us if we can make this document more accessible: pdxscholar@pdx.edu. 


\section{Authors}

Sharon J. Hall, J Learned, Benjamin Ruddell, Kelli L. Larson, Jeannine Cavender-Bares, Neil D. Bettez, Peter M. Groffman, J. Morgan Grove, James B. Heffernan, Sarah E. Hobbie, Kristen Larson, Jennifer L. Morse, Christopher Neill, Kristen C. Nelson, Jarlath O'Neil-Dunne, Laura A. Ogden, Diane E. Pataki, William D.

Pearse, Colin Polsky, Rinku Roy Chowdhury, Meredith K. Steele, and Tara Trammell 


\title{
Convergence of microclimate in residential landscapes across diverse cities in the United States
}

\author{
Sharon J. Hall • J. Learned • B. Ruddell • K. L. Larson • \\ J. Cavender-Bares $\cdot$ N. Bettez $\cdot$ P. M. Groffman - J. M. Grove \\ J. B. Heffernan - S. E. Hobbie · J. L. Morse • C. Neill • \\ K. C. Nelson • J. P. M. O'Neil-Dunne • L. Ogden • \\ D. E. Pataki - W. D. Pearse - C. Polsky • R. Roy Chowdhury • \\ M. K. Steele - T. L. E. Trammell
}

Received: 1 April 2015/ Accepted: 6 October 2015

(C) Springer Science+Business Media Dordrecht 2015

\begin{abstract}
Context The urban heat island (UHI) is a welldocumented pattern of warming in cities relative to rural areas. Most UHI research utilizes remote sensing methods at large scales, or climate sensors in single cities surrounded by standardized land cover. Relatively few studies have explored continental-scale climatic patterns within common urban microenvironments such as residential landscapes that may affect human comfort.
\end{abstract}

Special issue: Macrosystems ecology: Novel methods and new understanding of multi-scale patterns and processes.

Guest Editors: S. Fei, Q. Guo, and K. Potter.

Electronic supplementary material The online version of this article (doi:10.1007/s10980-015-0297-y) contains supplementary material, which is available to authorized users.

S. J. Hall $(\bowtie) \cdot$ J. Learned

School of Life Sciences, Arizona State University,

Tempe, AZ 85287, USA

e-mail: sharonjhall@asu.edu

B. Ruddell

Fulton Schools of Engineering, Arizona State University,

Tempe, AZ 85287, USA

\section{K. L. Larson}

Schools of Geographical Sciences and Urban Planning and Sustainability, Arizona State University, Tempe, AZ 85287, USA
Objectives We tested the urban homogenization hypothesis which states that structure and function in cities exhibit ecological "sameness" across diverse regions relative to the native ecosystems they replaced.

Methods We deployed portable micrometeorological sensors to compare air temperature and humidity in residential yards and native landscapes across six U.S. cities that span a range of climates (Phoenix, AZ; Los Angeles, CA; Minneapolis-St. Paul, MN; Boston, MA; Baltimore, MD; and Miami, FL).

Results Microclimate in residential ecosystems was more similar among cities than among native ecosystems, particularly during the calm morning hours. Maximum regional actual evapotranspiration (AET) was related to the morning residential microclimate effect. Residential yards in cities with maximum AET $<50-65 \mathrm{~cm} /$ year (Phoenix and Los Angeles) were generally cooler and more humid than nearby native

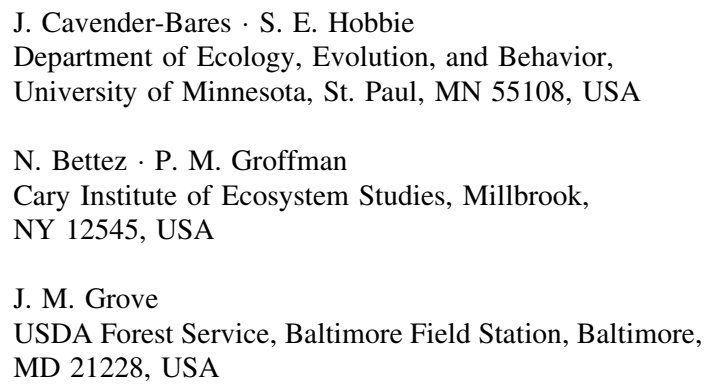

J. Cavender-Bares · S. E. Hobbie

Department of Ecology, Evolution, and Behavior,

University of Minnesota, St. Paul, MN 55108, USA

N. Bettez · P. M. Groffman

Cary Institute of Ecosystem Studies, Millbrook,

NY 12545, USA

J. M. Grove

USDA Forest Service, Baltimore Field Station, Baltimore, MD 21228, USA 
shrublands during summer mornings, while yards in cities above this threshold were generally warmer (Baltimore and Miami) and drier (Miami) than native forests. On average, temperature and absolute humidity were $\sim 6 \%$ less variable among residential ecosystems than among native ecosystems from diverse regions.

Conclusions These data suggest that common residential land cover and structural characteristics lead to microclimatic convergence across diverse regions at the continental scale.

Keywords Urban homogenization - Residential lawn · Microclimate - Urban heat island (UHI) · Humidity $\cdot$ Urban protected area

\section{Introduction}

Urban activities, land use, and the built environment significantly alter biophysical properties of air, water, and soil within cities and beyond. Observations about the peculiar characteristics of city air were first documented nearly four centuries ago and have since developed into an extensive field of urban climatology focused on the patterns and drivers of atmospheric phenomena at multiple scales (Jankovic 2013). Among the most well studied of these phenomena is the urban heat island (UHI), a widely observed pattern of warmer temperatures in urban compared with rural

\section{J. B. Heffernan}

Nicholas School of the Environment, Duke University, Durham, NC 27708, USA

\section{J. L. Morse}

Department of Environmental Science and Management, School of Environment, Portland State University,

Portland, OR 97207, USA

C. Neill

The Ecosystems Center, Marine Biological Laboratory, Woods Hole, MA 02543, USA

\section{K. C. Nelson}

Department of Forest Resources and Department of Fisheries, Wildlife, and Conservation Biology, University of Minnesota, St. Paul, MN 55108, USA

\section{J. P. M. O’Neil-Dunne}

Spatial Analysis Lab, Rubenstein School of Environment and Natural Resources, University of Vermont,

Burlington, VT 05405, USA areas. The UHI is caused by numerous factors related to land cover change and energy use, including waste heat from human activities, reduced vegetation cover in cities of mesic climates, and the extent and configuration of building materials that retain daytime heat and release it throughout the night (Oke 1982; Grimmond 2007). In cities of the United States, urban air temperatures have been increasing by $0.24{ }^{\circ} \mathrm{C}$ per decade in parallel with urban land expansion, nearly $50 \%$ faster than warming trends in rural areas $\left(0.16{ }^{\circ} \mathrm{C} /\right.$ decade; Stone et al. 2012).

Currently, nearly $80 \%$ of people in developed countries live in cities, and urban landscapes will be home to nearly three-quarters of the world's population in the coming few decades (UN 2014). Cities are often characterized by their extreme structural heterogeneity, as relatively continuous forests, grasslands, and agricultural lands are dissected by transportation corridors, buildings, vacant land, artificial water bodies, and a cosmopolitan mix of vegetation (Cadenasso et al. 2007). Social segregation within cities can also contribute to urban heterogeneity, which in turn shapes unequal access to and distribution of ecosystem amenities and disamenities like the UHI (Cole and Foster 2001; Jesdale et al. 2013).

The UHI is a generalizable feature of most cities, but its intensity varies significantly, driven in part by regional geographic characteristics and weather events that either stabilize and enhance the UHI or dissipate it (Imhoff et al. 2010; Zhao et al. 2014).

\author{
L. Ogden \\ Department of Anthropology, Dartmouth College, \\ Hanover, NH 03755-3529, USA \\ D. E. Pataki \\ Department of Biology, University of Utah, \\ Salt Lake City, UT 84112, USA \\ W. D. Pearse \\ Department of Biology, McGill University, Montréal, \\ QC H3A 0G4, Canada
}

W. D. Pearse

Département des Sciences Biologiques, Université du Québec à Montréal, Succursale Centre-ville, Montréal, QC, Canada

C. Polsky

Center for Environmental Studies, Florida Atlantic

University, Davie, FL 33314, USA 
Microclimate-defined as the climate of a small area that may be different from that in the general region (NOAA 2015)—also varies significantly within cities and at neighborhood scales depending on numerous factors associated with urban form. For example, actively transpiring plants create an evaporative cooling effect (or "oasis effect"), leading to significant daytime microclimate variation (Oke 1987; Jenerette et al. 2011). Neighborhoods near urban parks with trees and turfgrass appear on thermal maps as relatively cool patches within a warmer, built matrix (the "park cool island" and the "park breeze") (Spronken-Smith et al. 2000; Declet-Barreto et al. 2013), and this patchiness is related to household income. For example, in the desert city of Phoenix, Arizona, people in lower socioeconomic groups and ethnic minorities live in warmer neighborhoods because of lower neighborhood vegetation cover, and they are more likely to be exposed to extreme heat stress (Harlan et al. 2006). In contrast, Phoenix's wealthier neighborhoods contain more trees and irrigated lawns (Zhu and Zhang 2008; Jenerette et al. 2013), which leads to a $\sim 0.5{ }^{\circ} \mathrm{C}$ cooling benefit for every $\$ 10,000$ increase in annual household income (Jenerette et al. 2007).

Although cities are socially and micro climatologically heterogeneous at local scales, paradoxically, at regional and larger scales urban ecosystems appear to be quite similar across diverse geographies. For example, ubiquitous low-density suburbs-common to cities across the U.S. - are visually similar in their configuration of single family homes, green lawns, and cul-de-sacs (Cronon 1991; Kunstler 1993; Chowdhury et al. 2011). More recently, ecologists have hypothesized that urban sameness extends to biophysical properties and processes through homogenization of plant and animal communities, and convergence of landscape features in cities relative to the native

\section{R. R. Chowdhury}

Department of Geography, Indiana University,

Bloomington, IN 47405-7100, USA

\section{K. Steele}

Department of Crop and Soil Environmental Sciences, Virginia Polytechnic Institute and State University, Blacksburg, VA 24061, USA

\section{T. L. E. Trammell}

Department of Plant and Soil Sciences, University of Delaware, Newark, DE 19716, USA ecosystems that they replaced (McKinney 2006; Pouyat et al. 2007; Groffman et al. 2014). For example, soil properties and surface water distribution are relatively similar in urban areas across a range of climate zones, from deserts to forests (Groffman et al. 2014; Steele et al. 2014). Urban plants also tend to be similar in morphology and function, driven in part by similar disturbance regimes (Knapp et al. 2012), neighborhood social pressures (Robbins 2007), preferences for a suite of ecosystem services across socioeconomic groups (Larson et al. 2015), and a range of yard management practices that lead to a common aesthetic (Polsky et al. 2014).

As cities incorporate sustainability principles into their management decisions, more studies are exploring the drivers of urban microclimate variation to guide actions aimed at mitigating the negative effects of urban heating on human comfort and well-being (Chow et al. 2012). In much of the U.S., the most common landscape surrounding detached residential homes is composed of grass lawn and trees intermixed with buildings and pavement (Cook et al. 2012). Yards around homes may act as small parks, affecting temperature and humidity at "human" scales where people live. Moreover, following the urban homogenization hypothesis, the impact of yards on microclimate may be similar in cities across the country compared with surrounding native landscapes. Recent studies have explored the effects of residential neighborhood configuration and design elements such as green roofs and water-conserving, lawn-alternative landscapes on the UHI (Bonan 2000; Guhathakurta and Gober 2010; Chow and Brazel 2012; Peng and Jim 2013; Middel et al. 2014). However, to date no studies have measured how local habitats modify air temperature and humidity across diverse climate zones, or the extent to which common residential landscapes contribute to microclimatic homogenization. Indeed, ecological theories that integrate social-ecological phenomena are understudied at regional-to-continental scales (Heffernan et al. 2014).

In this paper, we ask, do residential landscapes in geographically distinct cities exhibit greater similarity in microclimate relative to the climates of nearby native habitats? Using small sensors, we compared air temperature and humidity in single-family residential yards and native landscapes across six U.S. cities that span a range of climate zones and ecosystem structure (Fig. 1). We hypothesized that microclimate converges in residential landscapes (i.e., lower variance 


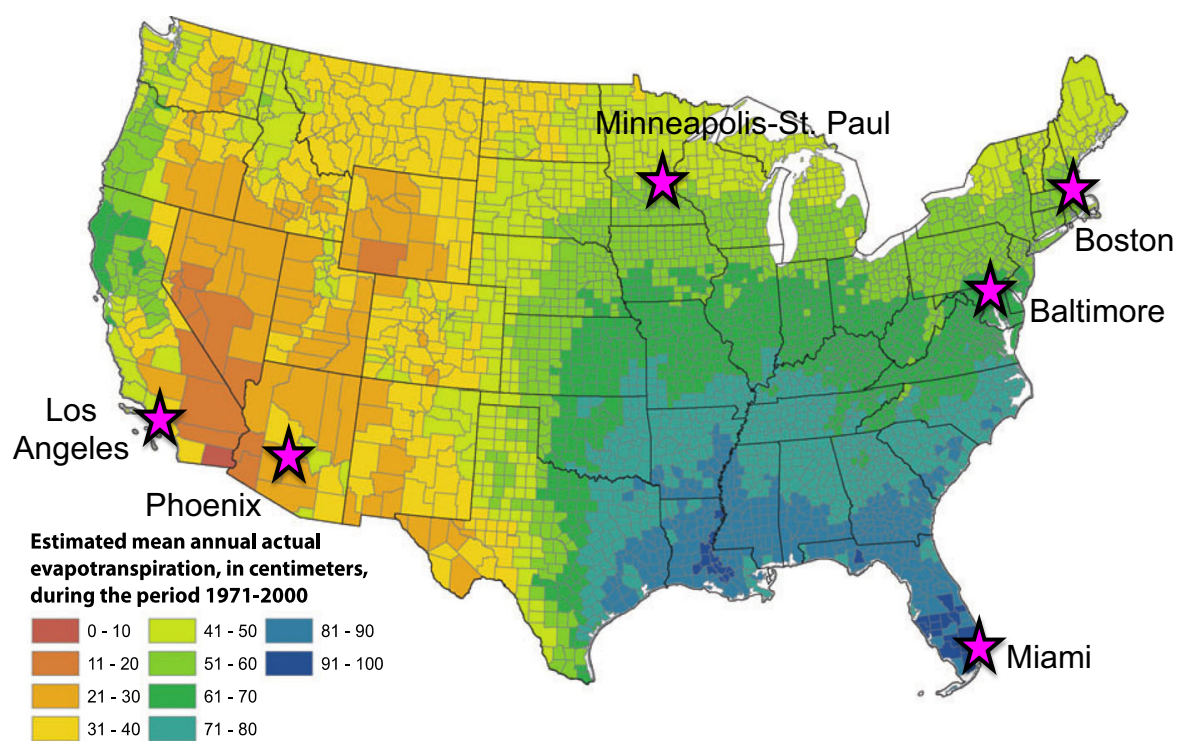

Fig. 1 Map of six study cities across regional climate zones in the US. Colors are estimated mean actual evapotranspiration (AET; cm/ year) from Sanford and Selnick (2013)

among cities) while microclimate is more distinct among near-city native habitats across regions (higher variance among cities). Specifically, we expected that residential landscapes within arid and semi-arid southwestern cities would be cooler and more humid than native shrublands, and yards in the humid eastern cities would be warmer and drier than native forests/grasslands. Drawing from known drivers of UHI intensity, we hypothesized that the strength of microclimate convergence across cities would vary at multiple temporal scales, with strongest convergence during summer and winter and during times when citywide atmospheric mixing is low (i.e., on calm days without synoptic weather events, and during the less windy, early hours before sunrise).

\section{Methods}

\section{Experimental design}

We compared sub-daily and monthly air temperature (T) and humidity (relative humidity, RH; absolute humidity, AH) in residential and native ecosystems in six cities using replicate microclimate sensors deployed in each ecosystem type (iButtons, Maxim Inc., San Jose, CA). The six study cities span a range of climate zones and ecosystem structure (Fig. 1) and included Phoenix, AZ; Los Angeles, CA; Minneapolis-St. Paul, MN;
Boston, MA; Baltimore, MD; and Miami, FL. Because our experimental design was intended to explore microclimate in local habitats, the geographic range of replicate residential and native sites in each city overlapped (Fig. 2). In other words, residential and native sites were not systematically split along urbanrural boundaries as in other UHI studies.

For the native ecosystem category, we selected 3-5 sites in parks or preserves within or near each city that were dominantly composed of minimally managed, primarily native vegetation (Fig. 2, Supplemental Fig. 1). Native sites were chosen to represent the range of heterogeneous vegetation types that were historically common in each region, including oak/tulip poplar forest (Baltimore), northern hardwood forest (Boston), coastal scrub (Los Angeles), pine rockland and subtropical hardwood hammock (Miami), tallgrass prairie/oak savanna/mixed hardwood forest (Minneapolis), and Sonoran Desert (Phoenix). Specific sites were identified from the range of possible minimally managed open space parcels in the metro areas of each city and ultimately limited to locations where permissions could be secured or where longterm monitoring was conducted as a part of the Longterm Ecological Research (LTER) network. For the residential ecosystem category, we chose replicate household parcels within each city using a stratified random experimental design. First, we compiled CLARITAS PRIZM market data to identify social 

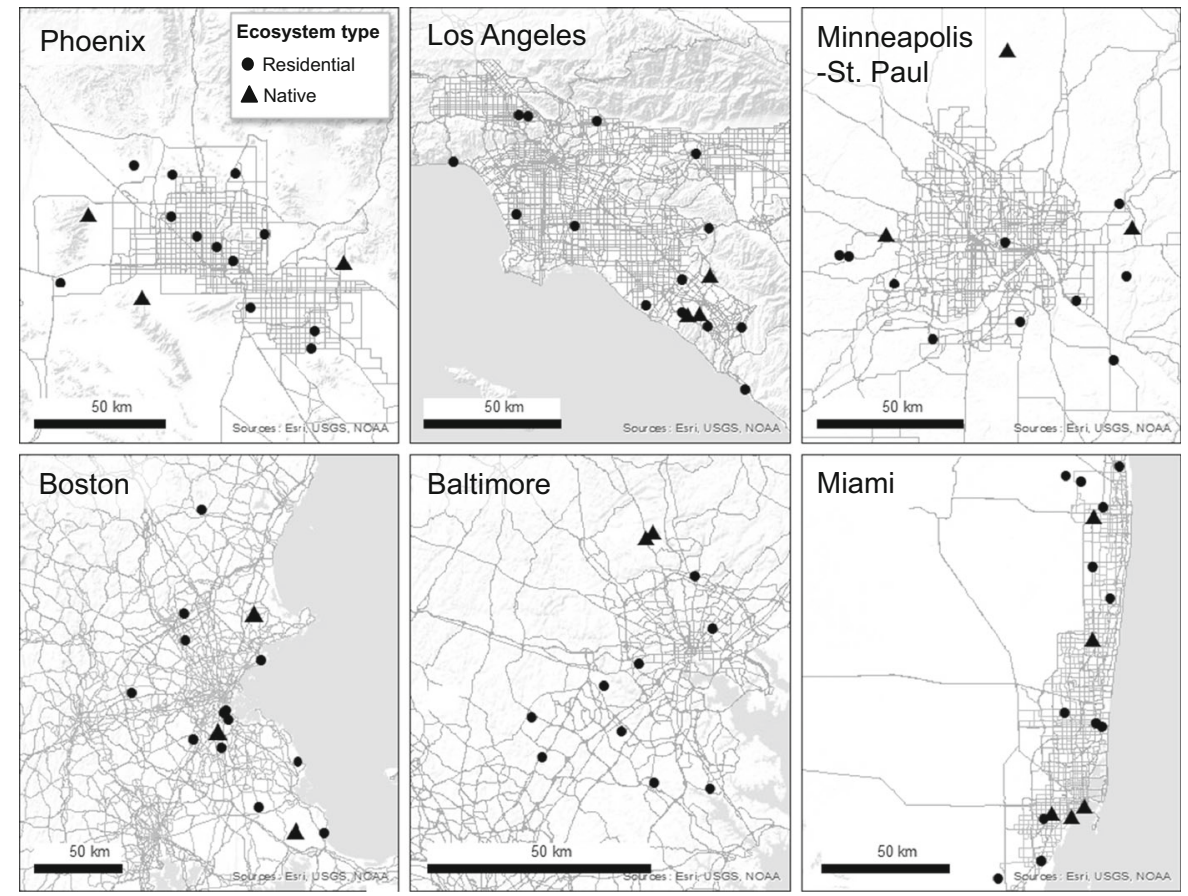

Fig. 2 Distribution of microclimate sensors within six study cities in the U.S. Circles and triangles are replicate residential yards of single-family homes and replicate native sites, respectively. Residential sites were chosen to span urban, suburban, and exurban density classes. Data from replicate

groups common to the six study cities (Polsky et al. 2014). From these categories, we identified singlefamily residences for inclusion in a telephone survey across classes of urban density (urban, suburban, and exurban), and socioeconomic status using income and lifestyle categories. Of the $>100,000$ households that were originally contacted for the telephone survey across all six cities, 13,590 people qualified for our study (over 18 years of age, and his/her single-family home had a front- or back-yard), 9480 participants completed the telephone survey (approximately equally distributed across all six cities), and 5797 participants agreed to be contacted for follow-up study. From a randomized list of follow-up participants, we contacted homeowners by mail and then telephone and selected the first 12-15 households who agreed to have microclimate sensors placed in their yards.

In each site, we placed iButton sensors inside a homemade gill-style radiation shield at $1.5 \mathrm{~m}$ above the ground (Supplemental Fig. 1). Gill-style radiation shields were made by vertically layering firm, foil-faced, white-painted bubble wrap (as the gills) separated by rigid wire to maximize aeration. One iButton sensor was sensors in each ecosystem type were averaged within cities to calculate sub-daily, citywide microclimate differences between residential and native landscapes $(\Delta \mathrm{T}$ and $\Delta \mathrm{AH})$. Note only two of the three sensors in native sites near Baltimore were operational during the year-long period analyzed here

suspended from wire (not touching the outside material) inside each gill-style shield. In each site, sensors were placed securely on poles or hung from tree branches ideally $>1 \mathrm{~m}$ from foliage or built structure. In all sites, sensors were located over the dominant ground cover (lawn, rock or organic mulch, bare ground, or other vegetation). Sensors were programmed to $\log \mathrm{T}$ and $\mathrm{RH}$ continuously at 1-h intervals, and data were downloaded every 1-3 months.

\section{iButton and radiation shield testing}

Prior to sensor deployment, we tested the accuracy of the iButtons and homemade radiation shields against the Arizona State University (ASU) weather station, a National Climate Data Center (NCDC)-standardized sensor in Tempe, AZ $\left(111^{\circ} 55^{\prime} 18^{\prime \prime} \mathrm{W}, 33^{\circ} 25^{\prime} 31^{\prime \prime} \mathrm{N}\right)$. iButtons and the modified shield systems that we used in this study have random errors but small population bias as expected based on the manufacturer's specifications. In April 2012, we hung three iButton sensors within gill-style shields on the outside of the ASU weather station for 2 days. Average air temperature 
from iButtons in the shields differed from the NCDCstandardized sensor by $0.7 \pm 0.5{ }^{\circ} \mathrm{C}$ (ranging from 0.1 to $2.3{ }^{\circ} \mathrm{C}$ ). Additionally, following data collection in the study cities, a subset of 31 iButtons that were removed from the field and shipped back to ASU were tested against a calibrated reference thermometer and hygrometer in the lab. Average differences between iButtons and lab sensors was $0.2 \pm 0.1{ }^{\circ} \mathrm{C}$ (ranging to $0.45{ }^{\circ} \mathrm{C}$ ) for $\mathrm{T}$ and $1.3 \pm 1.4 \%$ (ranging to $5.6 \%$ ) for RH. Additionally, the accuracy of the iButton sensor system used here is supported by an independent, extensive test of iButtons and improvised radiation shields in multiple cities (Marshall and Ruddell, unpublished). iButton temperatures measured using improvised gill-style radiation shields are biased $<1{ }^{\circ} \mathrm{C}$ compared with standard research-grade sensor systems (Hygroclip HC-S3 in a Young non-aspirated gilled radiation shield): iButtons are $<1{ }^{\circ} \mathrm{C}$ warmer after sunrise in morning and $<1{ }^{\circ} \mathrm{C}$ cooler before sunset in evening, with unbiased daily averages and values before sunrise, at midday, and after sunset.

\section{Data analyses}

In any given month, the number of operational sensors in residential yards and native sites ranged from 7 to 15 and 2 to 5 per city, respectively. Because of this low and uneven replication, within-city spatial variation in residential microclimate (e.g., by socioeconomic status) was not analyzed in this paper; rather, data from replicate sensors in residential yards (and in replicate native sites) were averaged within cities to compare citywide microclimate in residential versus native ecosystems.

Hourly $\mathrm{T}$ and $\mathrm{RH}$ data from each city were compiled, and major sensor inconsistencies (e.g. malfunction or location change) were removed from the dataset. RH data $>100 \%$ were changed to $100 \%$ maximum, and absolute humidity $\left(\mathrm{AH}, \mathrm{g} / \mathrm{m}^{3}\right)$ was calculated using the following formula (Mander 2012):

$$
\begin{aligned}
& \text { Absolute humidity }\left(\mathrm{g} / \mathrm{m}^{3}\right) \\
& =\frac{6.112 \times \mathrm{e}^{[(17.67 \times \mathrm{T}) /(\mathrm{T}+243.5)]} \times \mathrm{rh} \times 2.1674}{(273.15+\mathrm{T})}
\end{aligned}
$$

where $\mathrm{T}$ is temperature in ${ }^{\circ} \mathrm{C}$ and $\mathrm{rh}$ is relative humidity in \%. RH values are dependent on air $\mathrm{T}$ (while $\mathrm{AH}$ values are not); thus, analyses were conducted on $\mathrm{AH}$ as an independent metric from $\mathrm{T}$, and RH data are shown in the supplemental materials.
Hourly microclimate data were binned into five different times-of-day based on daily solar hours, including $20 \%$ of daily solar hours before sunrise, $20 \%$ of daily solar hours after sunrise, mid-day (50\% of solar hours after sunrise), $20 \%$ of daily solar hours before sunset, and $20 \%$ of daily solar hours after sunset. These times represent known daily weather transition periods (Hartmann 1994; Brazel et al. 2007). Although these times-of-day omit nighttime periods from several hours after sunset to before sunrise, they likely include daily minimum temperatures which typically occur just before dawn, and maximum temperatures which occur mid-afternoon (Brazel et al. 2000). To explore the effects of meteorological variables on microclimate patterns, we used the NCDC weather station at each city's airport to compile wind speeds by solar hours (minimum detection $1.3 \mathrm{~m} / \mathrm{s}$ ) and daily incidence of precipitation. We then grouped these data into times-of-day with low wind $(<3 \mathrm{~m} / \mathrm{s})$ and high wind $(\geq 3 \mathrm{~m} / \mathrm{s})$; and days that received precipitation (yes or no). Finally, we filtered the sub-daily dataset to include only those days with data from $\geq 2$ replicate sensors in residential and native land cover categories in each city.

In our analyses of convergence, we used data collected between August 2013 and July 2014 because this year-long period was most inclusive of data from all six study cities. Average daily $\mathrm{T}$ and $\mathrm{AH}$ in residential and native land cover categories were calculated from the 2-15 replicate sensors within each land cover (ecosystem) type across the five time-ofday bins. We then calculated differences between residential and native microclimate $(\Delta \mathrm{T}, \Delta \mathrm{RH}$, and $\Delta \mathrm{AH}$, residential-native) at each of the five timesper-day in each city.

We tested convergence by comparing monthly average $\mathrm{T}$ and $\mathrm{AH}$ in residential and native ecosystems, as well as the standard deviation of these variables among the six study cities. If variation between residential microclimates of the six cities was significantly smaller than variation between native microclimates, then we concluded that residential ecosystems converged. All statistical analyses were conducted in SPSS 22.0.0.1. Specifically, we tested convergence in microclimate first using a linear mixed model with monthly-average temperature and absolute humidity as dependent variables; month as a random factor; and ecosystem type (residential or native), time-of-day, and city as fixed factors. We also 
tested convergence using a linear mixed model with the standard deviation of the mean monthly $\mathrm{T}$ and $\mathrm{AH}$ (among six cities) as dependent variables; month as a random factor; and ecosystem type (residential or native) and time-of-day as fixed factors. We modeled only interactions between fixed factors that included our main variable of interest (e.g., ecosystem type, with city $x$ time-of-day and other interactions without ecosystem type excluded from the model). We compared models (random intercept alone or in combination with random slopes for fixed factors) with different covariance structures (diagonal, variance components, first-order autoregressive, compound symmetry) using the second-order Akaike Information Criterion $\left(\mathrm{AIC}_{\mathrm{c}}\right)$ and accepted the model with the lowest $\mathrm{AIC}_{\mathrm{c}}$ value (and any other models with $\mathrm{AICc}$ values $\leq 2$ relative to the best one). Prior to all linear model analyses, we transformed dependent variables to meet assumptions based on inspection of residuals.

We also explored the relationship between daily and monthly average $\Delta \mathrm{T}$ and $\Delta \mathrm{AH}$ (residentialnative; dependent variables) and common ecosystemrelated variables that describe the regional environment in which the cities occur, including maximum regional actual evapotranspiration (in $\mathrm{cm} /$ year, abbreviated to max AET; estimated from Fig. 1, Sanford and Selnick 2013) and the ratio of mean annual precipitation (P) to potential evapotranspiration (PET), which is a measure of ecosystem waterlimitation (Budyko 1974; Jones et al. 2012). P/PET values for the selected study cities were estimated from Cheng et al. (2011) and were as follows: 0.29 (Phoenix), 0.33 (Los Angeles), 0.38 (Miami), 0.47 (Baltimore), 0.75 (Minneapolis-St. Paul), and 1.0 (Boston). Using data from the 4 months for which all six cities had operational sensors (Sept 2013, October 2013, May 2014, and July 2014), we ran a linear mixed model with transformed daily $\Delta \mathrm{T}$ (or $\Delta \mathrm{AH}$ ) as the dependent variable; month as a random variable; $\max$ AET (or P/PET) as a covariate, and time-of-day as a categorical fixed factor. Additionally, we used linear regression to estimate the relationship between monthly-average $\Delta \mathrm{T}$ (or $\Delta \mathrm{AH}$ ) and the regional ecosystem-related variables (max AET or P/PET), split by month and time-of-day. Dependent variables were transformed to meet linear model assumptions.

Finally, to explore the effect of regional atmospheric conditions on daily $\Delta \mathrm{T}$, we conducted linear mixed model analyses with the absolute value of daily
$\Delta \mathrm{T}$ as a dependent variable (i.e., to size of the deviance from zero); month as a random factor (Aug 2013-July 2014); wind speed (low, high) and rain (yes, no) as fixed factors, and city (as max AET) as a covariate. For this model, we used data from two times-of-day where wind speeds are likely to differ (after sunrise and before sunset). Linear mixed model selection methods were conducted as described above.

\section{Results}

Climate differed significantly among the six cities and times-of-day across the year (Fig. 3, Supplemental Fig. 2a-c), and reflected the wide geographic range of sites included in this study. Averaged across both residential and native habitats, average mid-afternoon temperatures in January 2014 ranged from $-10{ }^{\circ} \mathrm{C}$ (Minneapolis-St. Paul) to $22{ }^{\circ} \mathrm{C}$ (Miami), and in July 2014 ranged from $24{ }^{\circ} \mathrm{C}$ (Minneapolis-St. Paul) to $42{ }^{\circ} \mathrm{C}$ (Phoenix). Humidity was equally variable among cities. In January, average afternoon absolute humidity ranged seven-fold, from $2 \mathrm{~g} \mathrm{H}_{2} \mathrm{O} / \mathrm{m}^{3}$ (Minneapolis-St. Paul) to $14 \mathrm{~g} \mathrm{H}_{2} \mathrm{O} / \mathrm{m}^{3}$ (Miami). In July, afternoon humidity ranged twofold, from $11 \mathrm{~g} \mathrm{H}_{2} \mathrm{O} /$ $\mathrm{m}^{3}$ (Phoenix) to $22 \mathrm{~g} \mathrm{H}_{2} \mathrm{O} / \mathrm{m}^{3}$ (Miami). Monthlyaverage wind speed as measured at the airport also varied across cities (Supplemental Fig. 3), but daily wind speeds were generally higher in mid-afternoon than morning [Pearson's Chi square test across all cities, wind speed $\times$ time-of-day (after sunrise vs. before sunset) interaction, $\mathrm{p}<0.001]$. Cities also differed in the number of days they received rainfall during the Aug 2013-July 2014 study period (Supplemental Table 1).

Despite major differences in city-wide climate, microclimates in residential ecosystems converged across the six study cities compared with native ecosystems. Absolute differences between ecosystem types (residential and native) were relatively small compared to the range of temperature and humidity across cities (Fig. 3). However, residential ecosystems were generally more humid and cooler than native ecosystems in the arid/semi-arid cities of Phoenix and Los Angeles, particularly in the morning, and were less humid and either similar to or warmer than native grasslands and forests in the wetter cities of Minneapolis-St. Paul, Boston, Baltimore, and Miami (Fig. 3; linear mixed model with month as random 
Fig. 3 Monthly average air temperature $\left({ }^{\circ} \mathrm{C}\right)$ and absolute humidity $\left(\mathrm{g} / \mathrm{m}^{3}\right)$ in the six study cities, Phoenix (PHX), Los Angeles (LOS), Minneapolis-St. Paul (MSP), Boston (BOS), Baltimore (BAL), and Miami (MIA). Error bars indicating variance within a month ( \pm 1 SE) are smaller than the markers and are thus not shown

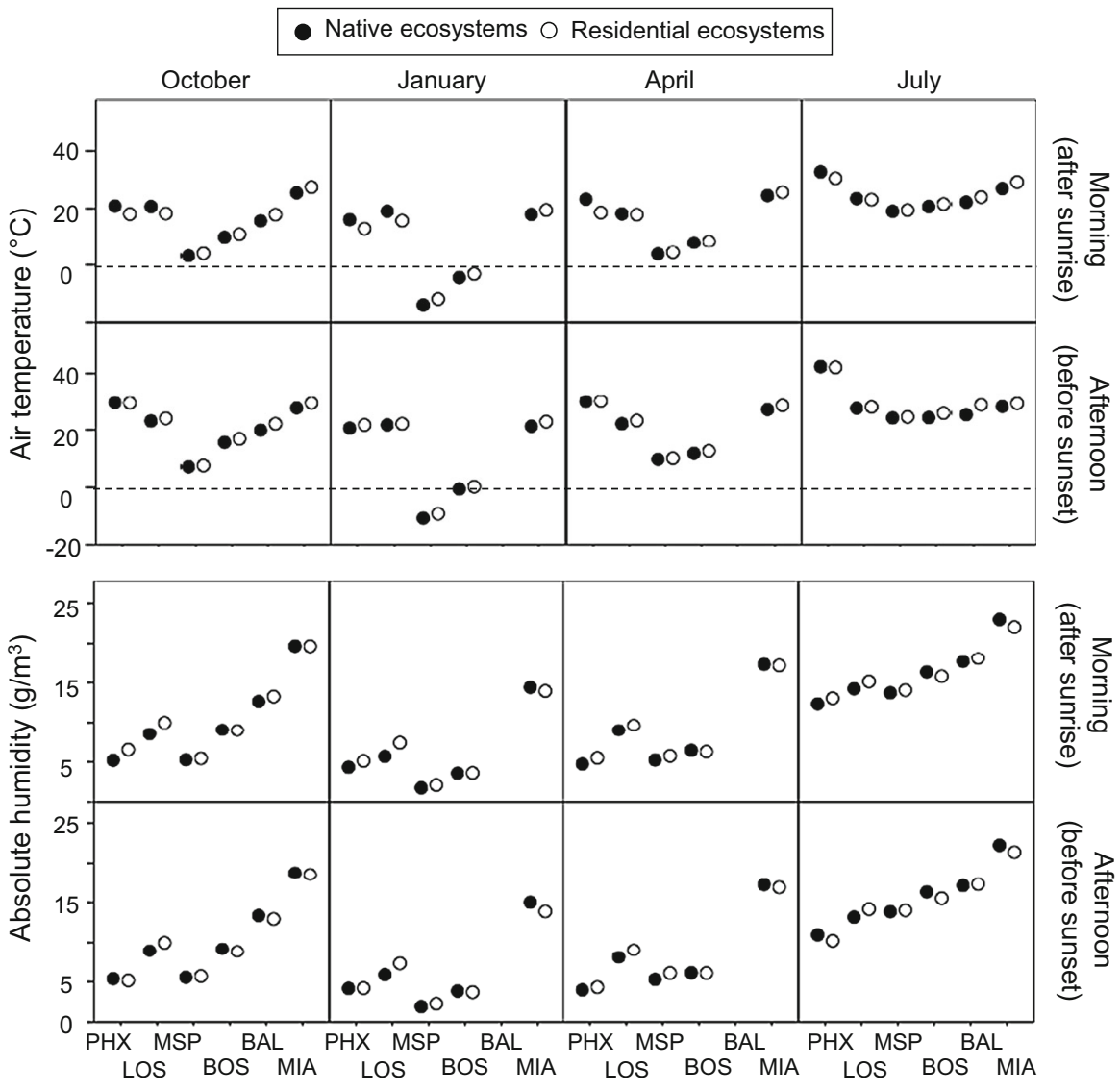

factor; monthly average $\mathrm{T}$ and $\mathrm{AH}$ as dependent variables, ecosystem type $x$ city interaction, $p<0.001$ for both $\mathrm{T}$ and $\mathrm{AH}$ ). The significance of these patterns depend on time-of-day (Figs. 4, 5, and Supplemental Fig. 4 for $\Delta \mathrm{RH}$; monthly average $\mathrm{T}$ and $\mathrm{AH}$ (dependent); ecosystem type $\times$ city $\times$ time-of-day interaction, $\mathrm{p}<0.001$ for both $\mathrm{T}$ and $\mathrm{AH}$ ). Differences in temperature between native and residential landscapes were strongest during the atmospherically calmer and more stable morning hours after sunrise.

Indicating microclimatic convergence at the continental scale, the standard deviation of temperature and humidity among residential landscapes of six cities was smaller than the standard deviation among six native ecosystems (Fig. 6; Standard deviation of monthly average $\mathrm{T}$ and $\mathrm{AH}$ among cities as dependent variables, month as random factor; ecosystem type and time-of-day as fixed factors; ecosystem type, $\mathrm{p}<0.001$ for both $\mathrm{T}$ and $\mathrm{AH})$. However, the strength of convergence in air temperature depended on the time of day (Fig. 6; time-of-day, $\mathrm{p}=0.03$; ecosystem $\times$ time-of-day interaction, $\mathrm{p}<0.001$ ). On average, both $\mathrm{T}$ and $\mathrm{AH}$ were $\sim 6 \%$ less variable among residential ecosystems from diverse regions than among native ecosystems from these regions. Convergence was strongest during the seasonal extremes (mid-winter and mid-summer; Fig. 6) and, for temperature, in morning.

Supporting our hypotheses, mid-summer morning differences in $\Delta \mathrm{T}$ and $\Delta \mathrm{AH}$ across the six regions (i.e., the residential microclimate effect, residential minus native within cities) were significantly related to native ecosystem structure as approximated by maximum regional evapotranspiration (max AET; cm/yr) (Fig. 7; see Supplemental Figs. 5 and 6 for daily variance within months). Residential ecosystems were increasingly warmer and drier (less humid) than native ecosystems as regional AET increased. However, the strength of this relationship was inconsistent by month (linear regression, monthly averaged $\Delta \mathrm{T}$ and $\Delta \mathrm{AH}$ by maximum regional AET; Supplemental Table 2). In July, 


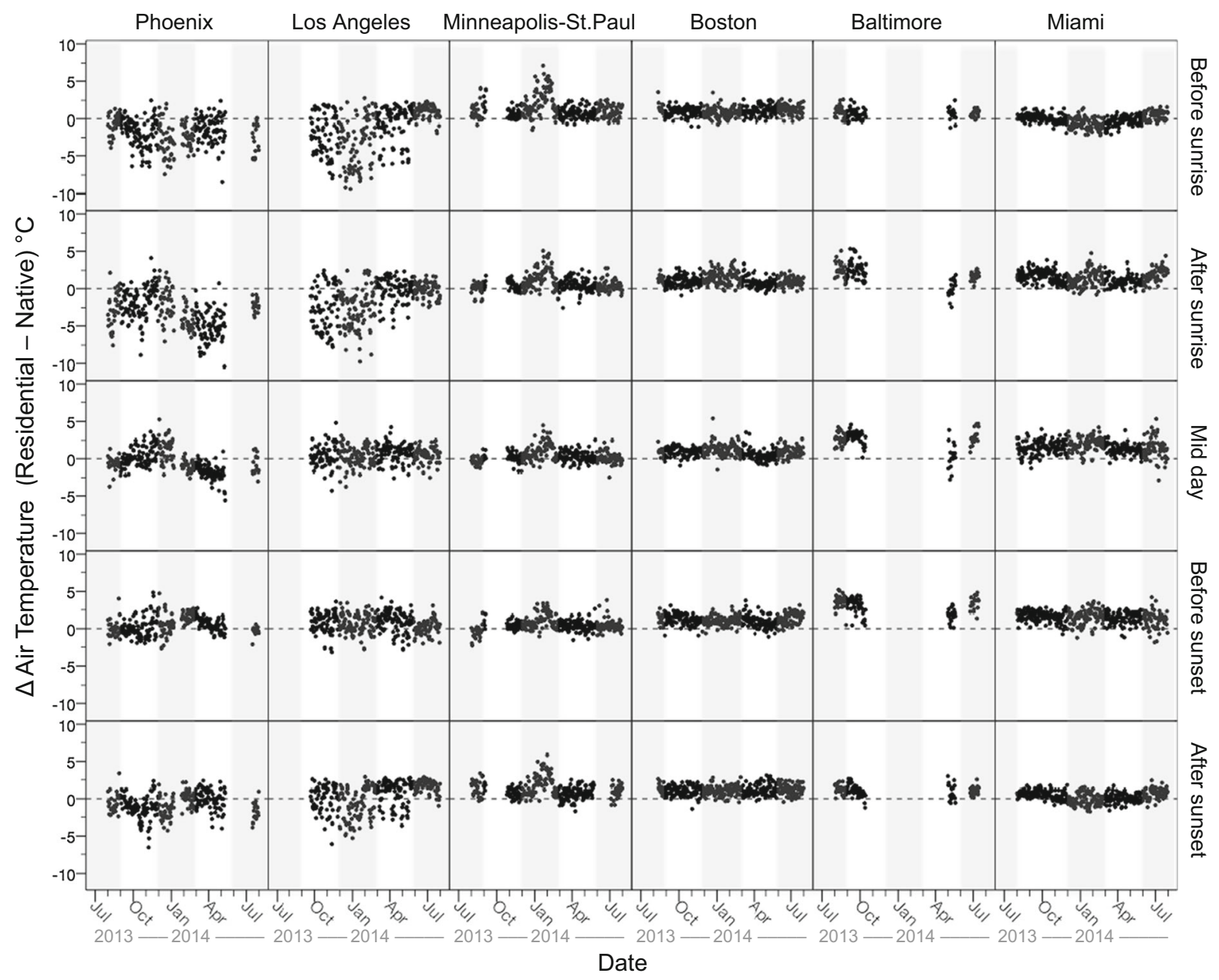

Fig. 4 Daily $\Delta \mathrm{T}\left({ }^{\circ} \mathrm{C}\right)$ across the study period, separated by time-of-day. Dots represent the daily difference between the average of 7-15 residential yards and the average of 2-3 native ecosystems in each city. Shaded dates are summer and winter

morning $\Delta \mathrm{T}$ and $\Delta \mathrm{AH}$ were closest to zero (i.e., minimum residential microclimate effect) in cities with a maximum regional AET between 50 and $65 \mathrm{~cm} /$ year, closest to the climates of MinneapolisSt. Paul and Boston (Fig. 7). In contrast, monthly average microclimate differences between residential and native ecosystems were not significantly explained by P/PET, a common index of ecosystem water limitation, which is the ratio of annual $\mathrm{P}$ to annual PET (Supplemental Table 2).

The difference in air temperature between residential and native habitats (i.e., the size of the absolute deviation of $\Delta \mathrm{T}$ from zero) was significantly related to time-of-day, precipitation, and wind (Supplemental Fig. 7; also Figs. 4 and 5; wind and time-of-day are correlated). However, contrary to our hypotheses, the strength of this relationship differed across all geographic regions. In other words, heterogeneous mechanisms underlie patterns of microclimate homogenization in residential landscapes across cities. For example, the morning temperature effect of residential ecosystems decreased at higher wind speeds common in the afternoon in Los Angeles but was increased in Miami (Supplemental Fig. 7; mixed model with data from Miami and Los Angeles, only before sunrise and after sunset times-of-day included, month as random factor; categorical wind speed and rain as fixed factors and max AET as a covariate: wind $\times$ max AET interaction, $\mathrm{p}<0.001$; precipitation $\times$ wind $\times \max$ AET interaction, $\mathrm{p}<0.001$ ). 


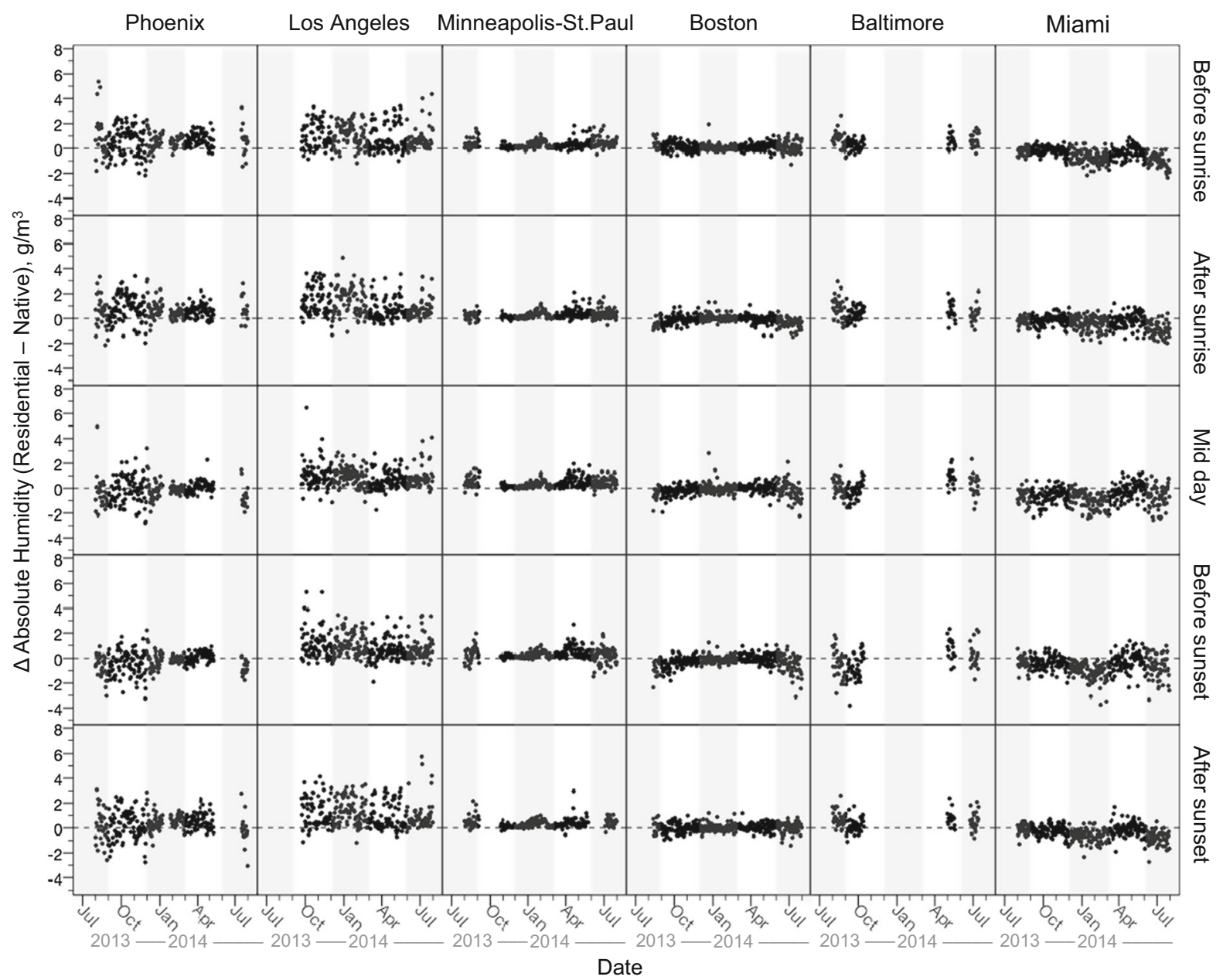

Fig. 5 Daily $\Delta \mathrm{AH}\left(\mathrm{g} / \mathrm{m}^{3}\right)$ across the study period, separated by time-of-day. Dots represent the daily difference between the average of $7-15$ residential yards and the average of 2-3 native

\section{Discussion}

Microclimate measurements in urban and native landscapes across the US reveal patterns not detected by standardized sensor networks that are sited to minimize the influence of local habitats. Residential microclimates across different metropolitan areas converged, particularly during winter and summer mornings. Averaged across all seasons of the year, yards of single-family homes in arid/semi-arid southwestern cities of Phoenix and Los Angeles were $11 \%$ more humid (absolute) and $2.2{ }^{\circ} \mathrm{C}$ cooler on average than native desert and shrublands within several hours after sunrise (up to $\sim 10{ }^{\circ} \mathrm{C}$ cooler temperatures and $\sim 45 \%$ higher relative humidity on some days). In the ecosystems in each city. Relative humidity $(\Delta \mathrm{RH}, \%)$ is dependent on temperature and is shown in Supplemental Fig. 4. Shaded dates are summer and winter

northern and northeastern metropolitan areas of Minneapolis-St. Paul, Boston, and Baltimore, average residential temperatures after sunrise were $0.7{ }^{\circ} \mathrm{C}$ (MSP) to $2.0^{\circ} \mathrm{C}$ (BAL) warmer than mixed woodlands and forests, and up to $5{ }^{\circ} \mathrm{C}$ warmer during winter in MSP. In the southeastern city of Miami, yards in the morning were on average $1.5{ }^{\circ} \mathrm{C}$ warmer and $2 \%$ less humid (absolute) than native subtropical forests, and ranged to $\sim 30 \%$ lower relative humidity than native forests on some afternoons.

The residential landscape effect on humidity remained significant through late afternoon, but cross-city differences in air temperature between yards and native habitats were less distinct during mid-day and afternoon, as yards were mostly similar to 
Fig. 6 Convergence in microclimate among the six study cities depends on the season and time of day. Shown is the difference in the standard deviation of the mean of six native and residential ecosystems (representing six cities). Points above the dotted line show that variance among urban residential ecosystems is lower than among native ecosystems; below the line is the opposite. The asterisk signifies that microclimate from Phoenix is missing in June 2014

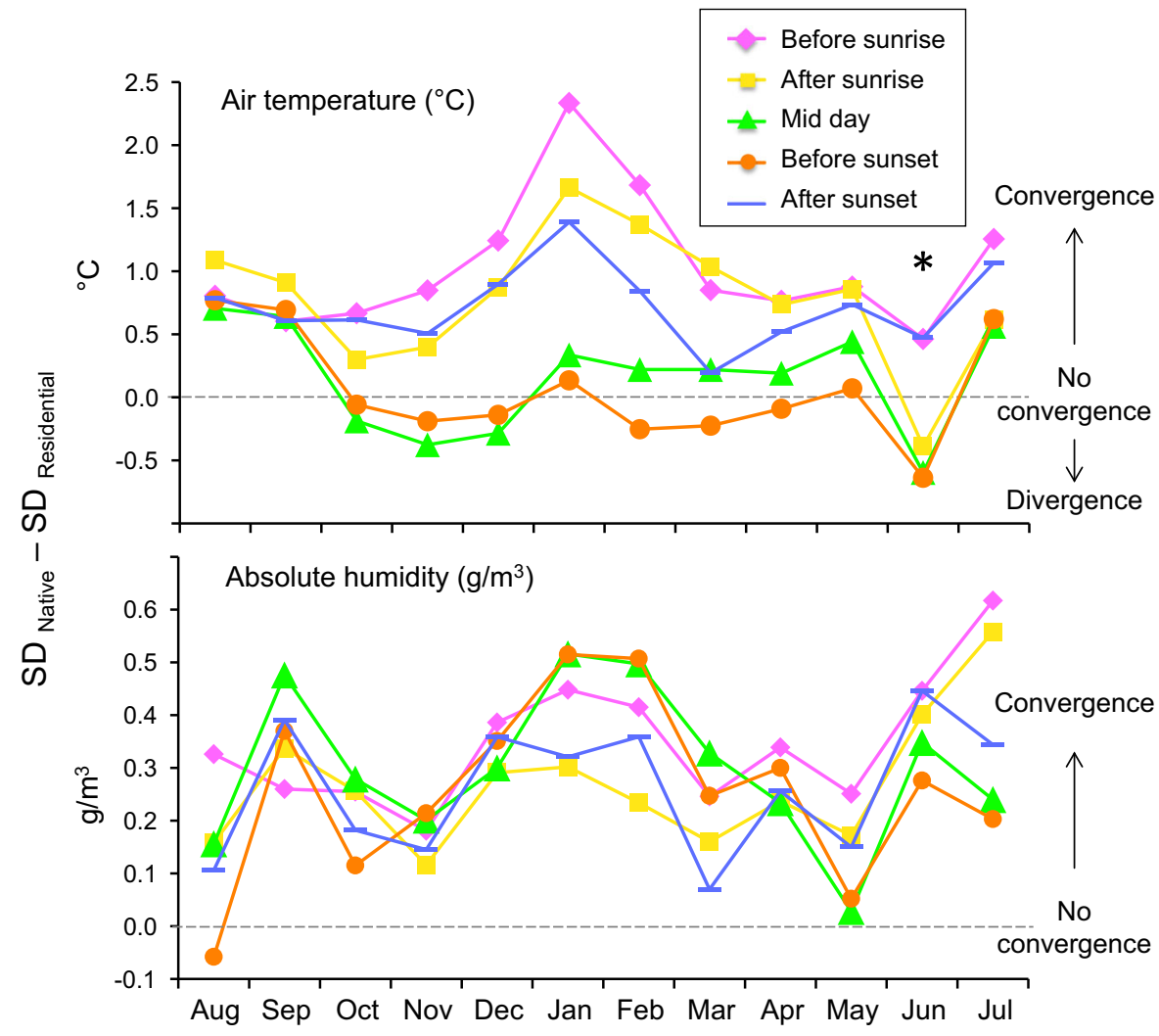

or slightly warmer than native landscapes. The reduction in residential microclimate convergence appears to be related in some cities to wind speed and atmospheric mixing, which on average is highest in the afternoon between mid-day and sunset. Atmospheric mixing across the city can dissipate local-scale "habitat" effects of transpiring vegetation and shade. Differences in the strength of convergence across the day may also be related to high afternoon surface temperatures of residential pavements and buildings (i.e., the classic UHI phenomenon) that may offset the cooling effect of grass and trees because of an accumulation of heat from absorbed solar radiation (Imhoff et al. 2010).

The microclimate patterns described here were evident even within the context of the broader citywide UHI pattern of heating in urban relative to rural locations. For example, previous research in most of our selected cities showed that urbanized areas were significantly warmer at night compared with areas outside of the city boundaries (Brazel et al. 2000; Zhang et al. 2004; Imhoff et al. 2010; Wong and
Chaudhry 2012; Kenward et al. 2014). The native sites used in this study were located within the same geographic range as residential sites, and in some cases the two were closely intermingled within the urban matrix (see Supplemental Fig. 2). Thus, our research shows that within this larger-scale UHI pattern, distinct microclimates occur within residential landscapes at "human" scales that are relevant to people and the non-human organisms that share residential habitats. For example, our data show that microclimates in residential yards were still distinct from native habitat patches during the late evening and into the pre-sunrise hours. This pattern shows that, while the UHI leads to nighttime warming in most cities, local vegetation and urban form cause variation in microclimate at finer scales, resulting in complex implications for human comfort depending in the regional climate and season.

The residential microclimate effect (i.e., the extent to which residential and native habitats differ within cities), appeared to be related to native (rain-fed) ecosystem structure as approximated by regional rates 


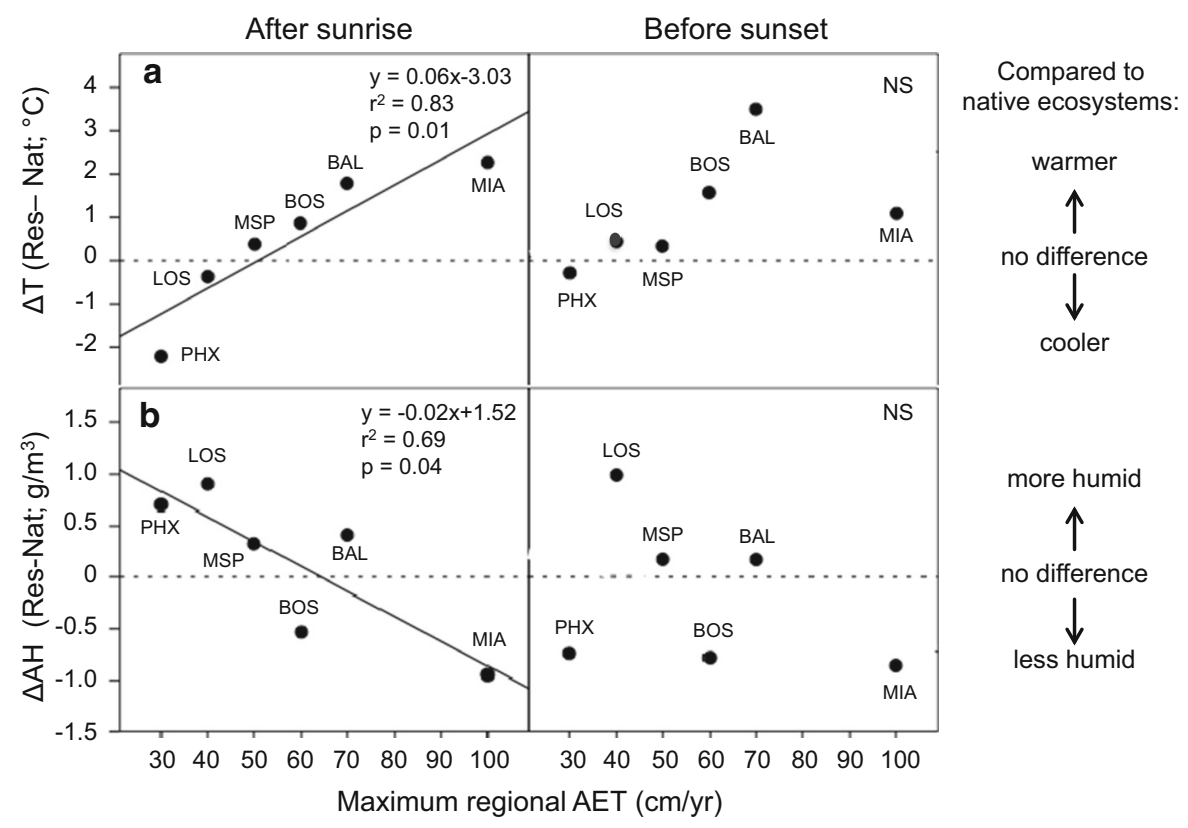

Fig. 7 Mid-summer (July), morning microclimate differences between residential and native landscapes are related to continental patterns of evapotranspiration (maximum regional AET from Fig. 1; Sanford and Selnick 2013). a $\Delta$ Air temperature $\left({ }^{\circ} \mathrm{C}\right)$ and $\mathbf{b} \Delta$ Absolute humidity $\left(\mathrm{g} / \mathrm{m}^{3}\right)$. $P H X$ Phoenix, LOS Los Angeles, MSP Minneapolis-St. Paul, BOS Boston, BAL Baltimore, MIA Miami. NS not significant.

of evapotranspiration. Microclimate convergence across the six study cities was likely caused by human modification of evapotranspiration in residential landscapes, with the strongest effects at the extremely wet and dry ends of the climate gradient. Irrigated turfgrass and trees cooled and humidified the atmosphere in Phoenix and Los Angeles where urban vegetation cover was more extensive and productive-and much more regularly watered-than native shrublands (Buyantuyev and Wu 2009; Litvak et al. 2013). In Miami's residential areas, decreased tree and vegetation cover (Nowak and Greenfield 2012) and impervious surfaces that route rainfall away from homes appeared to warm and dry the microclimate compared with dense, native subtropical forest and moist soils that retain rainfall. These patterns support the findings of other cross-city and modeling studies that show that daytime patterns of evapotranspiration and cooling are driven by the configuration and fraction of land covered by vegetation (Dimoudi and Nikolopoulou 2003; Middel et al. 2012). Additionally, the microclimate patterns shown here may be influenced by the
Statistics are from a linear regression between maximum regional AET (cm/year) and monthly average $\Delta \mathrm{T}$ and $\Delta \mathrm{AH}$ in July $(\mathrm{N}=6)$. Daily variance of $\Delta \mathrm{T}$ and $\Delta \mathrm{AH}$ within months is shown in Supplemental Fig. 5. Linear regression results from the other months in which all six cities have data are in Supplemental Table 2

apparent continental-scale convergence of hydrological features in US cities, which results in more surface water in dry cities and less surface water in wet cities compared with native ecosystems (Steele et al. 2014). Factors related to native ecosystem structure also drive temperature variation at city-wide scales. For example, UHI intensity varies across biomes. In cities of dry climates, urban surfaces are more aerodynamically rough compared with surrounding shrublands and lead to a daytime cooling effect from enhanced convection and increased dissipation of heat (Zhao et al. 2014). In contrast, cities in temperate, mixed broadleaf forest biomes experience significant daytime heating from reduced tree cover, which leads to $8{ }^{\circ} \mathrm{C}$ higher summer surface temperatures on average than rural lands (Imhoff et al. 2010). In warm-humid biomes like in southern Florida, UHI intensity is less than expected based on temperate cities of comparable size because of overall high ambient cloud cover that reduces solar heating, and high soil moisture and subtropical vegetation cover that reduces sensible heat flux (Roth 2007). 
Interestingly, the metropolitan areas where the summer residential microclimate effect was smallest was in the temperate cities of Boston and MinneapolisSt. Paul. Residential yard tree cover in Boston was the highest of all of the study sites ( $~ 85 \%$ compared with $\sim 40 \%$ in Phoenix), comparable to the dense cover in native mixed coniferous and broadleaf forest habitats within and surrounding the Boston metropolitan area. In Minneapolis-St. Paul, microclimate within the mixed grass-tree habitats of residential yards appeared to be similar to native grassland-woodland savanna habitats typical of natural areas of east-central Minnesota (Wendt and Coffin 1988). Suburban landscapes have been compared with natural rocky savanna ecosystems with their mix of trees, grass, and hard surfaces that create open, park-like vistas ("urban savanna" and "urban cliff" landscapes; Orians 1986; Gobster 1994; Larson et al. 2004; Lundholm 2006). The replication of residential rock-savanna landscapes across the country has been hypothesized to contribute to homogenization of plant communities (Lundholm and Marlin 2006), although other studies suggest that urban vegetation assemblages are more strongly related to resident preferences for plants that provide shade and natural beauty, and plant functional traits associated with disturbance (St. Hilaire et al. 2010; Knapp et al. 2012; Avolio et al. 2015). Despite the visual similarity of "urban savannas" in residential ecosystems nationwide, however, the absolute temperature and humidity modification by residential habitats was small compared with regional climate differences.

Optimal outdoor temperature and humidity contribute to human well-being (Stathopoulos et al. 2004). A temperature range of $21-27^{\circ} \mathrm{C}$ with a relative humidity of 30-65\% is generally regarded as the most pleasant environment for people (Cengel and Ghajar 2015). In contrast, at the extremes, heat and cold stress increases mortality risk in vulnerable populations (Curriero et al. 2002). Our data show that residential landscapes mitigate local humidity extremes, moderately increasing atmospheric moisture in cities of dry climates (Phoenix and Los Angeles from 30 to $40 \%$ $\mathrm{RH})$ and decreasing it in cities of the humid southeast (Miami, e.g. from 70 to $60 \% \mathrm{RH}$ ). High humidity is associated with pediatric asthma and tick-related disease in some cities (Gao et al. 2014), and is a driver of mortality in regions with warm climates, particularly those areas with highly vulnerable lowincome communities (Barreca 2012). On the other hand, both laboratory and epidemiological studies show that high atmospheric humidity $\left(>15 \mathrm{~g} / \mathrm{m}^{3}\right)$ reduces winter influenza transmission and survival in cool temperate climates comparable to the continental United States (Shaman and Kohn 2009; Tamerius et al. 2013; Lowen and Steel 2014). Thus, the observed convergence in residential microclimate, although minor, may result in both beneficial and detrimental effects on human residents.

Although absolute changes were small relative to variation across days and times-of-day, microclimate modification in residential landscapes could affect human comfort. For example, the Universal Thermal Climate Index (UTCI) is a common urban planning tool that estimates comfort (or discomfort) based on temperature, humidity, solar radiation, and wind; Błażejczyk et al. 2013; ClimateCHIP 2015). Assuming no changes between residential and native landscapes in radiation $\left(500 \mathrm{~W} / \mathrm{m}^{2}\right.$, scattered clouds) or wind speed $(1 \mathrm{~m} / \mathrm{s}$, relatively calm), we calculate that a slight increase in relative humidity (from 35 to $42 \%$ $\mathrm{RH}$ ) and $\sim 3{ }^{\circ} \mathrm{C}$ drop in summer morning air temperature (from 33 to $30{ }^{\circ} \mathrm{C}$ ) in Phoenix residential yards would reduce the UTCI from 39.1 ('very strong heat stress'; UTCI range of 38-46) to 36.5 (the upper end of 'strong heat stress'; UTCI range of 32-38) compared with native deserts. In contrast, residential landscapes in Baltimore during summer mornings are equal to or slightly less comfortable than native landscapes with all else equal, as a $2{ }^{\circ} \mathrm{C}$ morning warming $\left(22-24{ }^{\circ} \mathrm{C}\right)$ and a $7 \%$ drop in relative humidity $(89-82 \% \mathrm{RH})$ increases the UTCI from 32.0 to 33.5 (exacerbating strong heat stress, 32-38). On the other end of the seasonal spectrum, a $2{ }^{\circ} \mathrm{C}$ morning winter warming in residential yards in Minneapolis-St. Paul ( -14 to $-12{ }^{\circ} \mathrm{C}$ ) with a $4 \%$ increase in humidity $(81-85 \%$ $\mathrm{RH}$ ) augments human thermal comfort from a UTCI of -2.5 to -0.29 (slightly warmer within the category of moderate cold stress, 0 to -13 ).

These examples generally illustrate potential microclimate impacts on human comfort and are unlikely to represent real-world conditions. For example, thermal comfort is significantly affected by wind and solar radiation, and these variables likely differ in complex ways between residential and native ecosystems across climate zones (Dimoudi and Nikolopoulou 2003; Bang et al. 2010). Also, people do not spend significant amounts of time in near-urban native habitats or outdoors as a whole, and the UTCI 
categories generalize across known variation in thermal comfort among different types of people (e.g., culture, clothing differences by gender, etc.; Klepeis et al. 2001; Lin et al. 2010; Bröde et al. 2012). Furthermore, human thermal comfort is relatively high during the moderate morning hours when residential landscapes are most distinct from native landscapes compared with the daily extremes of mid-afternoon (near maximum temperature) or during the night (near minimum temperatures) when thermal stress is most acute. Nevertheless, human populations differ in the time they spend outside (Klepeis et al. 2001), and socio-economically disadvantaged people are at a higher risk for extreme climate and pollution exposure (Wu et al. 2010; Mitchell and Chakraborty 2014). An understanding of the drivers of within-city microclimate patterns at regional scales could offer constraints and opportunities for the design of safe, comfortable outdoor spaces for people. Furthermore, a better understanding of the relationship between native habitats and urban microclimate could contribute to the restoration success or preservation of open-spaces, parks, and even residential landscapes composed of native biotic communities and cover.

\section{Conclusion}

Despite major differences in city-wide climate, microclimates in residential ecosystems converged across the six study cities compared with native ecosystems. This convergence was especially strong during the morning hours but also occurs after sunset during the seasonal climatic extremes of mid-winter and midsummer. However, heterogeneous mechanisms related to wind, precipitation, regional climate, and native ecosystem structure underlie patterns of microclimate homogenization across cities such that no single factor sufficiently explained the microclimate effects we observed at all times of day and year and in all cities. There is a strong need for further analysis of human-scale variation in microclimate within different areas of the city environment. Such analysis will become increasingly important with climate change in future decades in order to guide design and management of microclimate in residential and other urban habitats for both people and non-human organisms.

Residential landscapes are generally valued by people for a range of common ecosystem services, and they moderated microclimate extremes compared with native habitats in most of the cities studied here (Cook et al. 2012; Larson et al. 2015). However, many of the benefits associated with a green, comfortable, and attractive yard come at a significant cost associated with management, including capital and labor, and environmental problems related to irrigation, fertilization, and pesticide use (Robbins et al. 2001; Larson et al. 2010; Carey et al. 2013; Martini et al. 2013; Polsky et al. 2014). As cities consider social-ecological sustainability as a guiding principle in planning decisions (APA 2000), citizens and decision makers should consider the numerous trade-offs associated with these and other management practices. Although residential landscapes across the country were microclimatically more homogeneous on average than native landscapes, the direction of change and implications for human comfort depended on geographic context associated with regional ecosystem structure. Similarly, the best management practices for urban sustainability are likely to vary by city and will need to be tailored to the local climate, ecology, and sociocultural context.

Acknowledgments We are grateful to numerous technical staff, students, and volunteers who assisted with microclimate data collection, including Erin Barton, Matthew Camba, Emma Dixon, La'Shaye Ervin, Caitlin Holmes, Richard McHorney, Miguel Morgan, Joseph Rittenhouse, Anna Royar, Jehane Samaha, Sydney Schiffner, Julea Shaw, Anissa Vega, Elisabeth Ward, and Megan Wheeler. We also thank Darrel Jenerette for reviewing an earlier draft of this manuscript. This project was supported by several collaborative grants from the Macrosystems Biology Program at NSF (EF-1065548, 1065737, 1065740, 1065741, 1065772, 1065785, 1065831, 1241960, and 121238320), and by the Earth Systems Modeling program at NSF (EF-1049251). This work was also supported in part by the NSF Long-term Ecological Research Program in Baltimore (BES LTER, DEB-0423476), Phoenix (CAP LTER, BCS1026865), Plum Island (PIE LTER Boston; OCE-1058747 and 1238212), Cedar Creek (CDR LTER, Minneapolis-St Paul; DEB-1234162), and Florida Coastal Everglades (FCE LTER, Miami; DBI-0620409).

\section{References}

APA (2000) Policy guide on planning for sustainability. Adopted by chapter delegate assembly, April 16, 2000; Ratified by Board of Directors, April 17, 2000. American Planning Association, New York, p 15

Avolio ML, Pataki DE, Pincetl S, Gillespie TW, Jenerette GD, McCarthy HR (2015) Understanding preferences for tree 
attributes: the relative effects of socio-economic and local environmental factors. Urban Ecosyst 18:73-86

Bang C, Sabo JL, Faeth SH (2010) Reduced wind speed improves plant growth in a Desert city. PLoS One 5(6):e11061. doi:10.1371/journal.pone.0011061

Barreca AI (2012) Climate change, humidity, and mortality in the United States. J Environ Econ Manag 63(1):19-34

Błażejczyk K, Jendritzky G, Bröde P, Fiala D, Havenith G, Epstein Y, Psikuta A, Kampmann B (2013) An introduction to the universal thermal climate index (UTCI). Geogr Pol 86(1):5-10

Bonan GB (2000) The microclimates of a suburban Colorado (USA) landscape and implications for planning and design. Landsc Urban Plan 49(3):97-114

Brazel AJ, Selover N, Vose R, Heisler G (2000) The tale of two climates: baltimore and Phoenix urban LTER sites. Clim Res 15:123-135

Brazel A, Gober P, Lee SJ, Grossman-Clarke S, Zehnder J, Hedquist B, Comparri E (2007) Determinants of changes in the regional urban heat island in metropolitan Phoenix (Arizona, USA) between 1990 and 2004. Clim Res 33(2):171-182

Bröde P, Krüger E, Rossi F, Fiala D (2012) Predicting urban outdoor thermal comfort by the universal thermal climate index UTCI: a case study in Southern Brazil. Int J Biometeorol 56(3):471-480

Budyko MI (1974) Climate and life. Academic Press, New York

Buyantuyev A, Wu J (2009) Urbanization alters spatiotemporal patterns of ecosystem primary production: a case study of the Phoenix metropolitan region, USA. J Arid Environ 73:512-520

Cadenasso ML, Pickett STA, Schwarz K (2007) Spatial heterogeneity in urban ecosystems: reconceptualizing land cover and a framework for classification. Front Ecol Environ 5(2):80-88

Carey RO, Hochmuth GJ, Martinez CJ, Boyer TH, Dukes MD, Toor GS, Cisar JL (2013) Evaluating nutrient impacts in urban watersheds: Challenges and research opportunities. Environ Pollut 173:138-149. doi:10.1007/s10980-015-0297-y

Cengel YA, Ghajar AJ (2015) Heating and cooling of buildings, chapter 16. Heat and mass transfer: fundamentals and applications, 5th edn. McGraw-Hill, London

Cheng L, Xu Z, Wang D, Cai X (2011) Assessing interannual variability of evapotranspiration at the catchment scale using satellite-based evapotranspiration data sets. Water Resour Res 47(9):W09509

Chow WTL, Brazel AJ (2012) Assessing xeriscaping as a sustainable heat island mitigation approach for a desert city. Build Environ 47:170-181

Chow WTL, Brennan D, Brazel AJ (2012) Urban heat island research in Phoenix, Arizona: theoretical contributions and policy applications. Bull Am Meteorol Soc 93(4):517-530

Chowdhury RR, Larson K, Grove M, Polsky C, Cook E, Onsted J, Ogden L (2011) A multi-scalar approach to theorizing socio-ecological dynamics of urban residential landscapes. Cities Environ 4(1):6

ClimateCHIP (2015) Excel heat stress calculator. Climate CHIP, climatechip.org, New Zealand

Cole L, Foster S (2001) From the ground up: Environmental racism \& the rise of the environmental justice movement. New York University Press, New York
Cook EM, Hall SJ, Larson KL (2012) Residential landscapes as social-ecological systems: a synthesis of multi-scalar interactions between people and their home environment. Urban Ecosyst 15(1):19-52

Cronon W (1991) Nature's metropolis: Chicago and the Great West, 1848-1893. W. W. Norton and Company, New York

Curriero FC, Heiner KS, Samet JM, Zeger SL, Strug L, Patz JA (2002) Temperature and mortality in 11 cities of the eastern United States. Am J Epidemiol 155(1):80-87

Declet-Barreto J, Brazel AJ, Martin CA, Chow WTL, Harlan SL (2013) Creating the park cool island in an inner-city neighborhood: heat mitigation strategy for Phoenix, AZ. Urban Ecosyst 16(3):617-635

Dimoudi A, Nikolopoulou M (2003) Vegetation in the urban environment: microclimatic analysis and benefits. Energy Build 35(1):69-76

Gao J, Sun Y, Lu Y, Li L (2014) Impact of ambient humidity on child health: a systematic review. PLoS One. doi:10.1371/ journal.pone.0112508

Gobster PH (1994) The urban savanna: reuniting ecological preference and function. Restor Manag Notes 12:64-71

Grimmond S (2007) Urbanization and global environmental change: local effects of urban warming. Geogr J 173(1):83-88

Groffman PM, Cavender-Bares J, Bettez ND, Grove JM, Hall SJ, Heffernan JB, Hobbie SE, Larson KL, Morse JL, Neill C, Nelson K, O’Neil-Dunne J, Ogden L, Pataki DE, Polsky C, Chowdhury RR, Steele MK (2014) Ecological homogenization of urban USA. Front Ecol Environ 12(1):74-81

Guhathakurta S, Gober P (2010) Residential land use, the urban heat island, and water use in Phoenix: a path analysis. J Plan Educ Res 30(1):40-51

Harlan SL, Brazel AJ, Prashad L, Stefanov WL, Larsen L (2006) Neighborhood microclimates and vulnerability to heat stress. Soc Sci Med 63(11):2847-2863

Hartmann DL (1994) Global physical climatology. Academic Press, New York

Heffernan JB, Soranno PA, Angilletta MJ Jr, Buckley LB, Gruner DS, Keitt TH, Kellner JR, Kominoski JS, Rocha AV, Xiao J, Harms TK, Goring SJ, Koenig LE, McDowell WH, Powell H, Richardson AD, Stow CA, Vargas R, Weathers KC (2014) Macrosystems ecology: understanding ecological patterns and processes at continental scales. Front Ecol Environ 12(1):5-14

Imhoff ML, Zhang P, Wolfe RE, Bounoua L (2010) Remote sensing of the urban heat island effect across biomes in the continental USA. Remote Sens Environ 114:504-513

Jankovic V (2013) A historical review of urban climatology and the atmospheres of the industrialized world. Wiley Interdiscip Rev 4(6):539-553

Jenerette GD, Harlan SL, Brazel A, Jones N, Larsen L, Stefanov WL (2007) Regional relationships between surface temperature, vegetation, and human settlement in a rapidly urbanizing ecosystem. Landscape Ecol 22(3):353-365

Jenerette GD, Harlan SL, Stefanov WL, Martin CA (2011) Ecosystem services and urban heat riskscape moderation: water, green spaces, and social inequality in Phoenix, USA. Ecol Appl 21(7):2637-2651

Jenerette GD, Miller G, Buyantuev A, Pataki DE, Gillespie T, Pincetl S (2013) Urban vegetation and income segregation in drylands: a synthesis of seven metropolitan regions in the southwestern United States. Environ Res Lett 8(4):044001 
Jesdale BM, Morello-Frosch R, Cushing L (2013) The racial/ ethnic distribution of heat risk-related land cover in relation to residential segregation. Environ Health Perspect 121(7):811-817

Jones J, Creed I, Hatcher K, Warren R, Adams M, Benson M, Boose E, Brown W, Campbell J, Covich A, Clow D, Dahm C, Elder K, Ford C, Grimm N, Henshaw D, Larson K, Miles E, Miles K, Sebestyen S, Spargo A, Stone A, Vose J, Williams M (2012) Ecosystem processes and human influences regulate streamflow response to climate change at long-term ecological research sites. Bioscience 62(4):390-404

Kenward A, Yawitz D, Sanford T, Wang R (2014) Summer in the city: hot and getting hotter. Clim Cent, Princeton, pp 1-29

Klepeis NE, Nelson WC, Ott WR, Robinson JP, Tsang AM, Switzer P, Behar JV, Hern SC, Engelmann WH (2001) The National Human Activity Pattern Survey (NHAPS): a resource for assessing exposure to environmental pollutants. J Expon Anal Environ Epidemiol 11(3):231-252

Knapp S, Dinsmore L, Fissore C, Hobbie SE, Jakobsdottir I, Kattge J, King JY, Klotz S, McFadden JP, Cavender-Bares J (2012) Phylogenetic and functional characteristics of household yard floras and their changes along an urbanization gradient. Ecology 93(8):S83-S98

Kunstler JH (1993) Geography of nowhere: the rise and decline of America's man-made landscape. Simon and Schuster, New York

Larson DW, Matthes U, Kelly PE, Lundholm JT, Gerrath JA (2004) The urban cliff revolution. Fitzhenry \& Whiteside, Toronto

Larson KL, Cook E, Strawhacker C, Hall SJ (2010) The influence of diverse values, ecological structure, and geographic context on residents' multifaceted landscaping decisions. Hum Ecol 38(6):747-761

Larson KL, Nelson KC, Samples SR, Hall SJ, Bettez N, Cavender-Bares J, Groffman PM, Grove M, Heffernan JB, Hobbie SE, Learned J, Morse JL, Neill C, Ogden LA, O'Neil-Dunne J, Pataki DE, Polsky C, Chowdhury RR, Steele M, Trammell TLE (2015) Ecosystem services in managing residential landscapes: Priorities, value dimensions, and cross-regional patterns. Urban Ecosyst 1-19

Lin T-P, Matzarakis A, Hwang R-L (2010) Shading effect on longterm outdoor thermal comfort. Build Environ 45:213-221

Litvak E, Bijoor N, Pataki D (2013) Adding trees to irrigated turfgrass lawns may be a water-saving measure in semiarid environments. Ecohydrology 7(5):1314-1330

Lowen AC, Steel J (2014) Roles of humidity and temperature in shaping Influenza seasonality. J Virol 88(14):7692-7695

Lundholm JT (2006) Green roofs and facades: a habitat template approach. Urban Habitats 4(1):87-101

Lundholm JT, Marlin A (2006) Habitat origins and microhabitat preferences of urban plant species. Urban Ecosyst 9:139-159

Mander P (2012) How to convert relative humidity to absolute humidity. https://carnotcycle.wordpress.com/2012/08/04/ how-to-convert-relative-humidity-to-absolute-humidity/. Accessed Jan 2015

Marshall T, Ruddell BL (unpublished) Performance evaluation of a low-cost printable radiation shield

Martini NF, Nelson KC, Hobbie SE, Baker LC (2013) Why “Feed the Lawn"? Exploring the influence of residential turf grass fertilization in the Minneapolis-Saint Paul Metropolitan Area. Environ Behav. doi:10.1177/0013916513492418

McKinney M (2006) Urbanization as a major cause of biotic homogenization. Biol Conserv 127:247-260

Middel A, Brazel AJ, Gober P, Myint SW, Chang H (2012) Land cover, climate, and the summer surface energy balance in Phoenix, AZ, and Portland, OR. Int J Climatol 32(13): 2020-2032

Middel A, Haeb K, Brazel AJ, Martin CA, Guhathakurta S (2014) Impact of urban form and design on mid-afternoon microclimate in Phoenix local climate zones. Landsc Urban Plan 122:16-28

Mitchell BC, Chakraborty J (2014) Urban heat and climate justice: a landscape of thermal inequity in Pinellas County, Florida. Geogr Rev 104(4):459-480

NOAA National Weather Service (2015) Glossary. www.nws. noaa.gov/glossary/. Accessed 7 Sept 2015

Nowak DJ, Greenfield EJ (2012) Tree and impervious cover change in U.S. cities. Urban For Urban Green 11:21-30

Oke TR (1982) The energetic basis of the urban heat island. Q J R Meteorol Soc 108(455):1-24

Oke TR (1987) Boundary layer climates. Methuen Publishing, London

Orians G (1986) An ecological and evolutionary approach to landscape aesthetics. In: Penning-Rowsell EC, Lowenthal D (eds) Landscape meanings and values. Allen and Unwin, London, pp 3-25

Peng LLH, Jim CY (2013) Green-roof effects on neighborhood microclimate and human thermal sensation. Energies 6(2):598-618

Polsky C, Grove JM, Knudson C, Groffman PM, Bettez N, Cavender-Bares J, Hall SJ, Heffernan JB, Hobbie SE, Larson KL, Morse JL, Neill C, Nelson KC, Ogden LA, O'Neil-Dunne J, Pataki DE, Chowdhury RR, Steele MK (2014) Assessing the homogenization of urban land management with an application to us residential lawn care. Proc Natl Acad Sci USA 111(12):4432-4437

Pouyat RV, Pataki DE, Belt KT, Groffman PM, Hom J, Band LE (2007) Effects of urban land-use change on biogeochemical cycles. Terrestrial ecosystems in a changing World. Springer, Berlin/Heidelberg/New York, pp 45-58

Robbins P (2007) Lawn people: how grasses, weeds, and chemicals make us who we are. Temple University Press, Philadelphia

Robbins P, Polderman A, Birkenholtz T (2001) Lawns and toxins: an ecology of the city. Cities 18(6):369-380

Roth M (2007) Review of urban climate research in (sub)tropical regions. Int J Climatol 27:1859-1873

Sanford WE, Selnick DL (2013) Estimation of evapotranspiration across the conterminous United States using a regression with climate and land-cover data. J Am Water Resour Assoc 49(1):217-230

Shaman J, Kohn M (2009) Absolute humidity modulates influenza survival, transmission, and seasonality. Proc Natl Acad Sci USA 106(9):3243-3248

Spronken-Smith R, Oke T, Lowry W (2000) Advection and the surface energy balance across an irrigated urban park. Int $\mathrm{J}$ Climatol 20:1033-1047

St. Hilaire R, VanLeeuwen DM, Torres P (2010) Landscape preferences and water conservation choices of residents in a high desert environment. HortTechnology 20(2):308-314 
Stathopoulos T, Wu H, Zacharias J (2004) Outdoor human comfort in an urban climate. Build Environ 39(3):297-305

Steele MK, Heffernan JB, Bettez N, Cavender-Bares J, Groffman PM, Grove JM, Hall S, Hobbie SE, Larson K, Morse JL, Neill C, Nelson KC, O’Neil-Dunne J, Ogden L, Pataki DE, Polsky C, Chowdhury RR (2014) Convergent surface water distributions in us cities. Ecosystems 17(4):685-697

Stone B, Vargo J, Habeeb D (2012) Managing climate change in cities: will climate action plans work? Landsc Urban Plan 107(3):263-271

Tamerius JD, Shaman J, Alonso WJ, Bloom-Feshbach K, Uejio CK, Comrie A, Viboud C (2013) Environmental predictors of seasonal Influenza epidemics across temperate and tropical climates. PLoS Pathog. doi:10.1371/journal.ppat. 1003194

UN (2014) World urbanization prospects: The 2014 Revision. Department of Economic and Social Affairs, Population Division, United Nations

Wendt KM, Coffin BA (1988) Natural vegetation of Minnesota at the time of the public land survey, 1847-1907. In: Winchell
NH (ed) Program. Minnesota Department of Natural Resources, pp 1-6

Wong KV, Chaudhry S (2012) Use of satellite images for observational and quantitative analysis of urban heat islands around the world. J Energy Res Technol 134(042101):1-8

Wu XM, Fan ZT, Ohman-Strickland P (2010) Time-location patterns of a population living in an air pollution hotspot. J Environ Public Health. doi:10.1155/2010/625461

Zhang X, Friedl MA, Schaaf CB, Strahler AH, Schneider A (2004) The footprint of urban climates on vegetation phenology. Geophys Res Lett. doi:10.1029/2004GL020137

Zhao L, Lee X, Smith RB, Oleson K (2014) Strong contributions of local background climate to urban heat islands. Nature 511(7508):216-219

Zhu P, Zhang Y (2008) Demand for urban forests in United States cities. Landsc Urban Plan 84(3-4):293-300 